\title{
Community Participation in Tourism Village Development in Tungkal Selatan Village, Pariaman Utara District, Pariaman City
}

\author{
Sarmiadi* \\ Tourism Study Program \\ Padang State Polytechnic \\ Padang, Indonesia \\ *sarmiadisarmiadi@gmail.com
}

\author{
Yosi Suryani, Elni Sumiarti \\ Business Administration Study Program \\ Padang State Polytechnic \\ Padang, Indonesia \\ yosisuryani@gmail.com, elnisumiarti@yahoo.co.id
}

\begin{abstract}
Pariaman City as one of the cities in the coastal area continues to develop its city by making tourism a leading sector. One of the villages that is very active in developing tourism as a means to improve the welfare of its people is Tungkal Selatan Village, Pariaman Utara District, which in early 2020 opened a tourist attraction. New Agro Wisata rides, ranging from hanging bicycles, flying foxes to hot air balloons. This tourist attraction is built based on ideas from the community and utilizes the potential that exists in the community as well. Judging from the stages of development of tourist objects, the existing tourist objects in South Tungkal Village are still new and under development. For this reason, a study is needed on the community-based tourism development model in this village. The development of the Tourism Village in Tungkal Selatan Village is only in the discovery stage because it was just discovered. This is in accordance with the conditions in the field that the existing facilities and markets have just been built. The development of this tourism village is built based on contributions from the community by involving other stakeholders, namely the government.
\end{abstract}

\section{Keywords—tourism village, community based tourism}

\section{INTRODUCTION}

Pariaman City as one of the cities in the coastal area continues to develop its city by making tourism a leading sector. Currently, many tourism objects are being developed in Pariaman City including Gandoriah Beach, Tugu Navy, Angso Duo Island, Anas Malik Park, Kata Beach. Pantai Cermin, turtle conservation, and mangrove tracks. Talao Park Pauh which has the theme of a waterfront city, Beruk College of Science, and the tourist village of South Tungkal. With the increasing number of these tourist attractions, in 2019 there was an increase in tourist visits to Pariaman City, which increased by around 600 thousand visits in 2019 or to 3.8 million from 2018 which only reached 3.2 million [1].

Even though it has increased, the Pariaman City Government is focusing on developing tourist destinations by maximizing the potential resources in the community (community based tourism). Many tourist objects are still managed by the community and many businesses have grown, such as restaurants, food / beverage traders and other supporting industries. The community-based tourism model is part of tourism practices which in practice provide renewal in the tourism sector [2].

Community-based tourism is tourism where the community or local residents play an important and major role in decision making to influence and benefit their lives and environment [3]. With this community involvement, opportunities for developing small-scale tourist objects and attractions can be managed by the local community so as to foster the local community's economy [3].

Sunaryo [4] states that the community as a stakeholder has an important position and role in supporting the success of tourism development. Starting from the planning framework to the implementation of tourism development activities, and to support the success of tourism development, every development effort or program implemented must pay attention to the position, potential and role of the community as the subject or actor of development. One of the concepts that explains the role of these communities in tourism development is Community Based Tourism (CBT).

One of the villages that is very active in developing tourism as a means of improving the welfare of its people is Tungkal Selatan Village, Pariaman Utara District. In the New Year 2020, the South Tungkal Village Government, North Pariaman District opened a new tourist attraction in the form of an Agro Tourism Forum, starting from hanging bicycles, flying foxes, to hot air balloons. This tourist attraction is built based on ideas from the community and utilizes the potential that exists in the community as well.

Judging from the stages of development of tourist objects, the existing tourist objects in South Tungkal Village are still new and under development. For this reason, a study of the community-based tourism development model in this village is needed in the form of research entitled Model Community 
Based Tourism in tourism development in Kota Pariaman (Case Study in Tungkal Selatan Village, North Pariaman District, Pariaman City).

\section{LITERATURE STUDY}

\section{A. Tourism Village}

Many regions have made their areas as tourist destinations through the concept of a tourist village. A tourism village is a community or community consisting of residents of a limited area who can interact with each other directly under a management and have concern, as well as awareness to play together according to their respective skills and abilities, empowering potential conducive to the growth and development of tourism in territory [5].

The tourism village places the community or society as the main subject or actor in tourism development, then uses it for the welfare of the community. In their social activities, selfhelp groups and community initiatives seek to increase understanding of tourism; accommodate the role and participation of the community in tourism development in the region; increase the value of tourism and empower it for the welfare of society [6].

As the main actor, the community or society seeks to increase the potential for tourism or tourist attractions in their area. Furthermore, the community or society prepares itself as a good host for tourists when visiting. All activities carried out by the community or community in tourist villages have the aim of improving the economic welfare of the community by utilizing their assets and potential.

\section{B. Community Based Tourism (CBT)}

The concept of Community Based Tourism (CBT) first appeared in Murphy's 1985 work related to tourism and management carried out by local communities, the concept (CBT) provides new pathways in research and opportunities in tourism development. (CBT) is characterized by the fact that the community has a control role over tourism management in receiving the impact of the benefits resulting from tourism activities [2].

Conceptually, the basic principles of community-based tourism are to position the community in tourism development as the main actor, and to involve the community's active participation in every activity. So that the community becomes a top priority in receiving benefits to improve welfare. The concept of community-based tourism has been used in carrying out directional actions by tourism development designers, so that in community development they can actively participate in supporting the tourism industry [5].

Community Based Tourism aims to ensure that the community is empowered in tourism development, opportunities for local communities to sell certain goods and services can be created through the development of cultural, social and environmental resources in the area. In other words, this type of tourism is considered a major tool in fighting / overcoming poverty, where community participation influences decisions about tourism programs and policies [7].

According to Suansri [8] "CBT is tourism that focuses on environmental, social, and cultural sustainability into one package. It is managed and owned by the community, for the community, with the aim of enabling visitors to increase their awareness and learn about the community and local ways. This type of tourism has emerged as a development solution in rural tourism areas that has an impact on local communities in obtaining economic, social and environmental benefits [9].

Suansri [8] mentions some of the principles of CommunityBased Tourism that must be carried out, namely:

- recognize, support and promote community ownership in tourism;

- involve community members from every stage of tourism development in various aspects;

○ Promote pride in the community concerned;

○ improve the quality of life;

○ Ensuring environmental sustainability;

○ protect the characteristics (uniqueness) and culture of local communities

○ develop cross-cultural learning;

○ respect for cultural differences and human dignity;

- Distribute profits and benefits proportionally to community members

- contribute a certain percentage of the income earned for community development; and

- Accentuate the authenticity of the community's relationship with the environment.

\section{Stages of Development of a Tourist Destination}

In developing tourism, both the development of destinations, tourism areas, and tourist attractions generally follow the flow or life cycle of tourism. The aim is to determine the position of tourism to be developed.

The stages consist of Buttler in Damanik and Weber [6]:

- The exploration stage is related to discovery, which is a place as a new tourism potential discovered by tourists, tourism actors, and the government. Usually the number of visitors is small, tourists are attracted to areas that are not yet polluted and deserted, the location is difficult to reach, but a small number of tourists are interested because they are not yet crowded.

- The involvement stage followed by local control, which is usually by the local community. At this stage there are initiatives from the local community, tourism 
objects are being promoted by tourists, the number of tourist's increases, and infrastructure begins to be built.

- The development stage and the presence of local control indicate a drastic increase in the number of tourist visits. Supervision by local institutions is rather difficult to produce results, the entry of the tourism industry from outside and the popularity of the tourist area has caused damage to the natural and socio-cultural environment so that there is a need for control intervention by local and national authorities.

- The consolidation phase (consolidation) with constitutionalism is shown by a decrease in the growth rate of tourist visits. The tourist area is filled with various tourism industries in the form of entertainment and various kinds of tourist attractions.

- The stage of stability (stagnation) is still followed by institutionalism, where the highest number of tourists has been reached and this area has begun to be abandoned because it is out of fashion, repeated visits and business people take advantage of existing facilities. At this stage there are efforts to maintain the number of tourists intensively carried out by the tourism industry and this area is likely to experience major problems related to the natural and socio-cultural environment.

- At the stage of decline in quality (decline) almost all tourists have diverted their visits to other tourist destinations. This area has become a small tourist attraction which is visited for a day or weekend. Several tourism facilities have been converted into other forms and functions. Thus, at this stage, government efforts are required to rejuvenate (rejuvenate).

- Rejuvenate stage, where in this stage it is necessary to consider changing the use of tourism areas, looking for new markets, creating new marketing channels, and repositioning tourist attractions to other forms. Therefore, new capital or cooperation between the government and the private sector is needed.

In order to attract tourists to visit it, a tourism village must meet six conditions, namely:

- "Something to see" which has a special attraction that can be seen by tourists.

- "Something to do", which has several recreational facilities or amusements and places or rides that tourists can use for their activities.

- "Something to buy", namely having souvenir items such as handicrafts from the local community that tourists can buy as souvenirs.

- "Something to arrive", which is to have the means to reach a tourist attraction which includes accessibility, transportation and estimated time of arrival at the location of the tourist attraction.
- "Something to stay" Yautu has facilities for tourists to stay during a visit to this tourist attraction.

- "Something to learn" means that there is something new experience that tourists get when visiting, thus increasing the knowledge of tourists.

The concept of developing a tourism village refers to the existence of $3 \mathrm{~A}$ elements in tourism and community involvement, namely [10]:

1) Attractions: Attractions in tourism are the main attractions of a tourist destination. Tourist attractions include everything that can be enjoyed by tourists, such as being seen, heard, felt or done, whether in the form of natural, cultural or creative results of the people. Natural attractions can be in the form of natural scenery, waterfalls, rivers, the presence of flora and fauna or others. Cultural attractiveness and creativity of the community can be in the form of museums, historical or ancient relics, art, agro tourism, recreational parks and entertainment venues. A good tourist attraction is, of course, not just something tourists can see or hear. Tourist attractions must be able to give the impression of experience to every tourist, so that the goal of carrying out tourism activities can be achieved. At an even better level, tourist attractions must be able to provide learning to every tourist or known as experiential learning (learning from experience).

2) Amenities: The amenities or supporting facilities of a tourist destination must be able to answer the needs of tourists while in a tourist location. Starting from basic facilities such as the existence of toilets, places of worship, parking lots, rest areas and places to eat. In addition, the existence of hotels or inns, restaurants or culinary places, places to buy souvenirs and all the supporting capacities that can complement tourism activities.

The completeness and comfort of the amenities that a tourist destination has, will influence tourists' considerations and decisions when they want to visit. The existence of these amenities will also affect the length of stay of tourists (length of stay) at tourist sites

3) Accessibility: Accessibility can be interpreted as a variety of things related to tourist access when they want to visit a tourist destination. This access includes access to information and access to transportation.

Access to information can be in the form of information about the attractiveness of a tourist destination, facilities and accommodations owned, travel information, and various other information needed by tourists before carrying out tourism activities. Access to information is also related to promotions carried out by a tourist destination to reach the wider community as potential tourists. At tourist locations, access to information can be in the form of the availability of a tourist information center or known as the TIC (Tourist Information Center) which makes it easy for every tourist to ask questions and obtain information related to tourism activities carried out. 
Transportation access can be in the form of the availability of public transportation such as planes, boats, trains, buses or other transportation needed by tourists to make it easier to reach a tourist destination. Apart from public transportation, the availability of good roads, signposts and the distance or distance traveled will affect the interest of tourists to visit.

A tourism village is an area within the village administration that has the potential for a unique tourist attraction along with the local wisdom of its people who are able to create a combination of various tourist attractions and supporting facilities to attract tourist visits. In managing a tourist village, it can be categorized into 3 (three) stages, namely piloting, developing, and being independent.

The development of a tourist village along with tourism products needs to be considered as follows:

- Authenticity

- Community Involvement

- Local Community Traditions

- Local wisdom values

- Conservation and Carrying Capacity

\section{Methodology}

This study uses qualitative descriptive methods with the aim of describing and thoroughly describing the phenomenon or situation of the case under study, using information obtained in depth and through data collection.

The formulation of the problem studied by the researcher is what are the stages of developing tourist objects in Tungkal Selatan Village, Pariaman Utara District, Pariaman City and how are the components involved in CBT in Tungkal Selatan Village, Pariaman Utara District, Pariaman City?

This research took place in Tungkal Selatan Village, Pariaman Utara District, Pariaman City. The data sources of this research are primary and secondary data sources with data collection techniques through observation, interviews, documentation and FGD (Focus Group Discussion). Data analysis used the stages of data collection, data condensation, data presentation and drawing conclusions.

\section{RESULTS AND DISCUSSION}

\section{A. Tourism Village Development Stages}

Tungkal Selatan Tourism Village, Pariaman Utara District was formed based on the desire and initiative of the community together with existing community leaders. Starting from the idea of utilizing existing land in the village, as well as making a visit to one of the tourist objects in Bandung, Community Leaders took the initiative to develop a new tourist attraction in Mereak Village, namely by providing hanging bicycles, hot air balloons. The development of this tourist attraction uses the
Village Fund and community participation in providing land for this tourist attraction. Based on the development stages.

Because it is still in the discovery stage, the number of visitors who come is still small and is dominated by local people. However, even though it is still new, information about this tourist village can be accessed through social media, namely Instagram.

\section{B. Community Participation in the Development of Tourism Village Destinations}

1) Local community participation: The development of tourist destinations that are built together with the community is strongly influenced by initiatives from the community so that the approach pattern is bottom up. If it comes from the community, community involvement will be maximized as happened in the village of Tungkal Selatan. The community sees that they have sufficient infrastructure, supported by an attractive view if used as a photo spot. This realized potential was followed by Community Leaders together with the Village Government to visit a Tourism Village in Bandung which has the same texture so that this emerged to build a tourist attraction by presenting hanging bicycle and hot air balloon facilities. The choice of this attraction is to provide an experience for tourists who come later supported by instagramable views.

Determination of the attractions offered was generated through intensive discussions between the community, youth leaders and village government. The community has ample opportunity to convey their aspirations and are given the opportunity to manage this tourist destination in the form of a Saiyo Tourism Awareness Group consisting of creative youths who are interested in developing tourism villages.

2) Establishment of a tourism village institution: To provide a forum for the community to manage tourist objects in South Tungka Village, the Government together with the Village community formed the Saiyo Tourism Awareness Group (Pokdarwis). Pokdarwis is tasked with managing and developing existing tourist objects. In its first year of establishment, 2019, Pokdarwis has carried out its duties based on leadership functions, internal partnerships, development of tourist attractions and enhancement of Human Resources. This role is carried out in coordination with the village government and community leaders in exploring the existing potential so as to encourage more community participation, such as people willing to donate their land for road access to tourist attraction locations. Pokdarwis also opens opportunities for people to open businesses in terms of providing food and beverages at tourist sites. Pokdarwis Saiyo also prepares existing resources in tourist objects, such as providing facilities for hanging bikes and hot air balloons as well as training operators who will serve tourists who come and want to use these facilities. Pokdarwis also sets rates for 
the use of existing tourist attractions and provides comfort for tourists. As a newly established organization, Pokdarwis Saiyo is still trying to organize the organization while still providing services to the people who come. Generally, this tourist attraction is crowded in the afternoon. The organizational arrangement of Pokdarwis Saiyo is focused on raising awareness of the administrators who have been formed to be serious in managing this destination because as a newly developed destination there are several challenges that require the management's attention. Managing tourist objects requires creativity and innovation as well as the cohesiveness of the administrators. The background of the Pokdarwis management who is not yet familiar with the tourism industry as a whole is also a challenge so that it requires training - training related to tourism object management. This of course requires coordination and partnerships with vocational universities as providers of skills for the community.

3) Establishment of community enterprises: With the opening of a tourist attraction in Tungkal Selatan Village, there will be opportunities for the economic movement of the community through the establishment of businesses managed by the local community. Now there are stalls that provide food and drinks for visitors who come at affordable prices. In the long term Pokdarwis Saiyo can encourage the local community to produce local specialties, making souvenirs typical of Tungkal Selatan Village that can be a memento for tourists who come. enjoy a tourism village product. In addition, with the increasing number of products that appear, the more people who are involved in enjoying the economic benefits of tourism activities in South Tungkal Village.

\section{Related Stakeholders Involvement in the Development of South Tungkal Tourism Village}

1) Role of community as actors: The people of South Tungkal Village have a big role in initiating and managing the tourist attractions in the village. Involvement has already started during planning, implementation and evaluation of activities. The community started with creative ideas since 2018 and could only be realized at the end of 2019 where these ideas can be realized through the construction of tourist objects such as hanging and hot air balloons. As a consequence of community involvement in development, the process of collecting ideas and making decisions takes a little longer, but with this community contribution it can make the development of tourism villages more optimal. It is hoped that with this community participation the economic benefits will be greater as well as a sense of belonging and the desire to maintain a better tourism object.

The role of the Government as facilitator of the South Tungkal Village Government has a strategic role as a facilitator and regulator in the development of tourist destinations. The government facilitates the community in utilizing existing resources and is able to coordinate the community in formulating development programs including the Development of the South Tungkal Tourism Village using the Village Fund. The use of village funds certainly requires an agreement with community leaders to ensure the sustainability of this tourist attraction. Government involvement will support the community to continue to develop this object and foster trust for tourists who will come.

2) Private role as developer / investor: In the development of tourism objects in Tungka Selatan Village, the private sector does not currently involve the private sector because this object was built with contributions from the community and village government. This condition will make it difficult for the private sector to play a role because it will clash with ownership of existing resources. The development of tourist objects that only comes from community contributions besides having a positive impact also has a weakness, namely the development of existing management will run slowly because it rests on the ideas and ideas of the community who have many opinions in decision making. People whose ideas are not accommodated may feel disappointed and hinder the development of existing tourist destinations.

\section{CONCLUSION AND RECOMMENDATION}

\section{A. Conclusion}

1) Stages of development of South Tungkal Tourism Deswa: The tourism objects in Tungkal Selatan Pariaman Tourism Village are still classified in the exploration stage related to discovery because these attractions have only been discovered by tourists, tourism actors, and the government.

2) Community participation in developing the tourism village: The South Tungkal Tourism Village was built through community contributions. The community has ample opportunity to convey their aspirations and are given the opportunity to manage this tourist destination in the form of a Saiyo Tourism Awareness Group consisting of creative youths who are interested in developing tourism villages.

3) The roles of stakeholders are involved in tourism village development: Management of tourist attractions in Tungkal Selatan Village involves tourism stakeholders. Related stakeholders involved in managing tourist attractions consist of community groups, government, but have not involved the private sector. The stakeholders involved have their respective roles to create management of tourist attractions.

\section{B. Recomedation}

In order for the development of the South Tungkal Tourism Village to be realized, the following are suggested:

- Increase the capacity of Pokdarwis Saiyo in managing existing tourist objects and carry out coordination functions with other stakeholders.

- Increased understanding of the community in managing existing tourist objects as well as the existence of 
written agreements, especially those related to the users of the resources that have been used (land) so that the possibility of future conflicts can be avoided.

- Regular meetings between all components of the community to formulate the program properly.

- Adding other experimental attractions when visiting Tungkal Selatan Village.

- Increase stakeholder participation to support the sustainability of the tourism village program in Tungkal Selatan Village.

\section{REFERENCES}

[1] https://www.sumbarfokus.com [Accessed on: April 25, 2020].

[2] D.P. Syah, Pengembangan Pariwisata Berbasis Masyarakat (Community Based Tourism) di Desa Wisata Banjarejo Kabupaten Grobogan.
Yogyakarta: Program Studi Ilmu Komunikasi, Fakultas Komunikasi dan Informasi, Universitas Muhammadiyah Yogyakarta, 2019.

[3] G.S. Sastrayuda, "Strategi Pengembangan dan Pengelolaan Resort and Leisure," Hand Out Mata Kuliah Concept Resort and Leisure, 2010.

[4] B. Sunaryo, Kebijakan pembangunan destinasi pariwisata: konsep dan aplikasinya di Indonesia (No. 1). Penerbit Gava Media Kebijakan Pembangunan Destinasi Pariwisata: Konsep dan Aplikasinya di Indonesia, 2013.

[5] H. Hermanto, Creative Based Tourism. Depok, Jawa Barat: Penerbit Aditri, 2011.

[6] J. Damanik dan H. Weber, Perencanaan Ekowisatadari Teori ke Aplikasi. Yogyakarta: CV. Anndi Offset, 2006.

[7] Word Tourism Organization, Tourism and Poverty Alleviation. Madrid: Word Tourism Organization, 2002.

[8] P. Suansri, Community Tourism Management Manual. Bangkok: Tourism for Life and Nature, 2003.

[9] M.C. Santos, C. Veiga, and P. Águas, "Tourism services: facing the challenge of new tourist profiles," Worldwide Hospitality and Tourism Themes, vol. 8, no. 6, pp. 654-669, 2016.

[10] O.A. Yoeti, Perencanaan dan Pengembangan Pariwisata. Jakarta: PT Pradnya Paramita, 1997. 